\title{
REFLEKSI TERHADAP EKSISTENSI DEWAN PERWAKILAN DAERAH REPUBLIK INDONESIA (DPD RI)
}

\author{
Efriza $^{1}$ \\ ${ }^{1}$ Program Studi Ilmu Politik, FISIP, Sekolah Tinggi Ilmu Pemerintahan Abdi \\ Negara (STIP-AN), Jakarta
}

\begin{abstract}
Abstrak
Penulisan ini bertujuan membahas perkembangan dinamika dan kinerja Dewan Perwakilan Daerah Republik Indonesia (DPD RI), setelah empat periode dihasilkan anggota-anggota DPD tetapi karena kewenangannya yang minimalis menyebabkan kinerjanya tak memuaskan. Malah, DPD bukannya diwacanakan kembali untuk diperkuat justru keinginan yang menguat adalah membubarkan DPD yang dianggap pemborosan anggaran negara saja. Sebab, tak dapat dipungkiri kinerja dan kiprahnya selama empat periode tidaklah istimewa selain hanya aksesoris belaka dari lembaga perwakilan kita yang lainnya.
\end{abstract}

Kata kunci: DPD, Senator, Kinerja, Amandemen Kelima

\section{Abstract}

This writing discusses the dynamics development and performance of the Regional Representative Council of the Republic of Indonesia (DPD RI), after a four-year period produced by DPD members due to their minimalistic authority causing unsatisfactory performance. Instead, the DPD is not being discouraged again to follow the strong desire of dismissing the DPD which says it is a waste of the state budget. Because, it is undeniable that performance and work during the four periods can be special in addition to mere accessories from our other representative institutions.

Keywords: DPD, Senator, Performance, Fifth Amendment

\section{PENDAHULUAN}

Posisi anggota Dewan Perwakilan Daerah (DPD) adalah para Duta Nusantara yang dipilih langsung oleh pemilih, sama halnya anggota Dewan Perwakilan Rakyat (DPR). Namun banyak pihak yang bertanya, mengapa fungsinya sebagai lembaga perwakilan daerah dibuat menjadi sangat terbatas. Keberadaaannya seperti "kerakap tumbuh di batu," dilahirkan tapi seolah tidak dikehendaki, DPD hadir dengan ketidakberdayaannya. Kehadirannya seolah diterima setengah hati. Ini adalah realitas yang harus diterima negeri ini bahwa adanya lembaga seperti Senator namun lemah 
dan menyedihkan berbagai kalangan. Biaya memilih dan dipilih anggota DPD sangat besar, namun fungsinya baru menjadi "pelengkap penyerta" di lembaga legislatif kita, hingga sekarang menjalani periode keempat lembaga tersebut, (Syafuan Rozi dan Efriza, 2010: 229).

Di satu sisi, tuntutan peningkatan peran dari DPD semakin besar di dorong oleh publik, hal ini bisa dipahami karena besarnya harapan daerah agar DPD dapat menjalankan fungsinya dengan baik untuk memperjuangkan berbagai permasalahan yang selama ini tidak dan belum diakomodir pusat. Berbagai kalangan lainnya menilai, DPD selama ini belum memperlihatkan kinerjanya secara maksimal yang dibuktikan dengan banyaknya aspirasi daerah yang belum jelas keputusannya. Padahal daerah mendambakan keputusan yang sesuai dengan apa yang menjadi harapan mereka, (Majalah Figur, Edisi XIII, 2007: 3).

DPD untuk kali pertamanya terbentuk setelah pemilihan umum (Pemilu) tahun 2004, kini memasuki periode keempat, dilahirkan melalui proses demokrasi yang mahal dan melelahkan. Tetapi kehadiran "DPD antara ada dan tiada," DPD memang ada antara lain karena memang ada lembaganya, menggunakan Anggaran Pendapatan dan Belanja Negara (APBN) dalam jumlah ratusan milyar rupiah setiap tahun untuk membiayai kegiatannya, dan ada kerjanya menyampaikan usul (puluhan) Rancangan Undang-Undang (RUU), menyampaikan ratusan pertimbangan kepada DPR, namun sebaliknya tiada hasil yang signifikan, termasuk tidak ada aspirasi daerah yang diwakili berhasil diperjuangkan dengan baik, (Ahmad Farhan Hamid, 2017: 6). Peran dan kewenangan DPD yang dinilai lemah dan masih minim itu, menyebabkan kini, muncul wacana agar peran dan kewenangan lembaga itu perlu diperkuat. Tetapi, jika tak kunjung diperkuat, muncul usulan agar DPD dibubarkan karena hanya memboroskan anggaran. Lembaga ini pun diasumsikan tak seperti lembaga perwakilan lainnya karena kewenangannya yang terbatas, DPD disejajarkan seperti Lembaga Swadaya Masyarakat (LSM) tetapi berplat merah. 
Seiring dinamika perkembangan atas institusi DPD, tatkala Mahkamah Konstitusi (MK) memperbolehkan anggota partai mendaftarkan diri sebagai calon anggota DPD dalam Pemilu 2009 lalu, serta meninjau perkembangan saat itu DPD berlarut-larut terlibat konflik dalam perebutan kursi pimpinan DPD dan juga institusi DPD mengalami degradasi nilai sejak Ketua DPD terpilih sebagai Ketua Umum Partai Hanura dan mengajak rekan-rekannya di institusi DPD untuk bersama-sama hijrah dengan cara merangkap jabatan sebagai anggota Partai Hanura sekaligus sebagai anggota DPD, sehingga keanggotaan DPD dan DPR terlihat sama bahkan institusi DPD lebih mirip sebagai Fraksi tambahan dalam tubuh DPR, realitas ini menyebabkan wacana membubarkan DPD kian lebih besar daripada menguatkan institusi ini.

Berdasarkan uraian-uraian di atas, menyembulkan rasa keinginan melakukan penelitian lebih lanjut, dengan mengupayakan untuk meninjau kembali terkait eksistensi DPD dalam hubungan relasi kekuasaan dengan DPR dalam proses kerja bersama sebagai institusi dua kamar dari lembaga perwakilan rakyat di Indonesia. Sehingga, Penulisan ini diharapkan dapat menjelaskan secara komprehensif mengenai sejarah dan dinamika hubungan kedua lembaga tersebut, agar dapat dihadirkan sebuah kesimpulan dasar terhadap dua arus pertentangan antara memperkuat institusi DPD atau malah membubarkan institusi DPD tersebut.

\section{METODE PENELITIAN}

Penulisan dalam penelitian ini dirancang dengan menggunakan pendekatan kualitatif yang menggunakan metode studi pustaka (library research). Teknik pengumpulan data dilakukan dengan mengadakan studi penelaahan terhadap buku-buku, literatur-literatur, dan laporan-laporan yang terkait dengan masalah yang ingin dipecahkan dalam penelitian ini (M. Nazir, 2003). Dalam melakukan prosedur studi pustaka bahwa informasiinformasi yang dihimpun dari sumber kepustakaan adalah yang relevan 
dengan penelitian ini, kemudian diteliti dan dianalisis serta dilakukan pengkajian akan kelemahan atau kekurangan dari penelitian-penelitian sebelumnya, sehingga kebaruan riset (novelty) dari hasil penelitian dalam penulisan ini dapat dihasilkan.

\section{KERANGKA TEORI}

Penelitian ini dalam melakukan penulisannya tentu diperlukan dukungan oleh teori atau konsep yang dapat membantu dalam menganalisis permasalahan. Ada tiga teori atau konsep yang digunakan yaitu: pertama, parlemen; kedua, fungsi legislasi; dan ketiga, mengenai struktur organisasi parlemen. Untuk memahaminya, uraiannya sebagai berikut.

\section{a. Lembaga Perwakilan Rakyat (Parlemen)}

Mengutip berdasarkan pernyataan Carl J. Friedrich, lembaga perwakilan rakyat atau biasa disebut parlemen, adalah lembaga utama dari pemerintahan perwakilan modern, yaitu sebagai majelis perwakilan rakyat (representatives assemblies) yang memunyai fungsi utama legislasi dan sebagai majelis tempat dilakukannya pembahasan (deliberative assemblies) untuk memecahkan berbagai masalah masyarakat dalam rangka melakukan pengawasan terhadap fiskal dan administrasi pemerintahan melalui speech and debate serta questions and interpellation, (A. Rosyid Al Atok, 2015: 206). Sedangkan, menurut Jimly Asshiddiqie, bahwa fungsi dari cabang kekuasaan legislatif yakni: terdiri dari fungsi pengaturan (legislasi), fungsi pengawasan (control), dan fungsi perwakilan (representasi), (Jimly Asshiddiqie, 2006: 32-34). Untuk lebih memahami mengenai lembaga perwakilan rakyat (parlemen) akan dijelaskan fungsi dari lembaga perwakilan antara lain dalam fungsi legislasi berikut ini.

\section{b. Fungsi Legislasi}

Fungsi legislasi berkaitan dengan kewenangan untuk membentuk peraturan perundang-undangan yang mengikat warga negara. Fungsi 
legislasi bisa dibedakan menjadi dua, yaitu fungsi legislasi dalam arti luas dan dalam arti sempit. Fungsi legislasi dalam arti luas termasuk di dalamnya membentuk Undang-Undang Dasar (UUD), sedangkan fungsi legislasi dalam arti sempit terbatas pada fungsi membentuk undangundang. Dalam penulisan penelitian ini bahwa pembentukan undangundang yang dimaksudkan adalah pembentukan undang-undang dalam arti sempit, yaitu pembentukan peraturan perundang-undang yang berupa undang-undang. Berkaitan dengan pelaksanaan fungsi legislasi dalam pembentukan undang-undang, menurut Jimly Asshiddiqie terdapat empat kegiatan yang meliputi: pertama, prakarsa pembuatan undang-undang; kedua, pembahasan rancangan undang-undang; ketiga, persetujuan atas pengesahan RUU; dan keempat, pemberian persetujuan pengikatan atau ratifikasi atas perjanjian dan persetujuan internasional dan dokumen-dokumen hukum yang mengikat lainnya, (Jimly Asshiddiqie, 2007: 159).

Keberadaan undang-undang sangatlah penting karena merupakan penjabaran lebih lanjut dari konstitusi. Maria Faria Indriati S. menyatatakan bahwa, "karena materi muatan konstitusi sebagai aturan dasar/pokok pada prinsipnya sangat terbatas pada hal-hal yang pokok dan mendasar, maka untuk bisa dilaksanakan secara aktual perlu dirumuskan lebih lanjut dalam aturan-aturan umum yang jelas dan terperinci dalam bentuk undang-undang dan selanjutnya perlu dijabarkan lebih teknis dan terinci dalam aturan pelaksana, (A. Rosyid Al Atok, 2015: 3)." Hal itu, menunjukkan bahwa undang-undang berada di tengah-tengah yang menjembatani antara konstitusi atau aturan dasar/aturan pokok dan aturan pelaksana.

\section{c. Struktur Organisasi Parlemen}

Mengenai struktur parlemen, pada prinsipnya struktur organisasi parlemen dibedakan berdasarkan jumlah majelis atau kamar 
yang ada di dalamnya. Jika di dalam parlemen terdapat hanya satu majelis disebut dengan sistem unikameral, dan jika di dalam parlemen terdapat dua majelis disebut bikameral, (A. Rosyid Al Atok, 2015: 207208).

Dalam sistem unikameral bahwa parlemen suatu negara hanya memiliki satu majelis yang melaksanakan semua fungsi parlemen, seperti fungsi pengawasan maupun fungsi pembuatan undang-undang. Sedangkan, dalam sistem bikameral parlemen suatu negara memiliki dua majelis yang melaksanakan semua fungsi parlemen, seperti fungsi pengawasan maupun fungsi pembuatan undang-undang.

Berdasarkan Andrews S. Ellis, bahwa ada dua alasan mengapa para penyusun konstitusi memilih sistem bikameral yaitu: pertama, untuk membangun sebuah mekanisme pengawasan dan keseimbangan (checks and balances) serta untuk pembahasan sekali lagi dalam bidang legislasi; dan kedua, membentuk perwakilan untuk menampung kepentingan tertentu yang biasanya tidak cukup terwakili oleh majelis pertama secara khusus, bikameralisme telah digunakan untuk menjamin perwakilan memadai untuk daerah-daerah di dalam lembaga legislatif. Meski begitu, hasil dari kesenjangan representasi di majelis kedua sangat bervariasi di dalam sistem dunia, (Reni Dwi Purnomowati, 2005: 1-10).

Setelah memahami alasan pembentukan sistem kamar kedua di atas, maka kita juga perlu memahami fungsi dari kamar kedua. Menurut Lord Bryce bahwa penjabaran klasik tentang fungsi dari second chamber atau kamar kedua dalam prakteknya memiliki empat macam fungsi, yaitu: pertama, perbaikan dari legislasi; kedua, awal mula dari rancangan yang tidak kontroversial; ketiga, penundaan legislasi dari konstitusi fundamental penting agar dapat memungkinkan suatu opini dari negara dapat cukup diungkapkan di 
atasnya; dan; keempat, debat publik atau pembahasan publik, (Reni Dwi Purnomowati, 2005: 14-15).

Dari pemahaman di atas, bahwa dalam sistem kamar kedua umumnya suatu Rancangan Undang-Undang (RUU) disahkan menjadi undang-undang setelah melalui pertimbangan di kedua majelis, hal ini merupakan proses yang normal dalam sistem bikameral. Jelas mungkin saja muncul ketegangan dan ketidakstabilan dalam sebuah sistem yang membolehkan terjadinya perdebatan untuk memilih dan menyetujui atau tidak menyetujui sebuah rancangan undang-undang terutama dalam sistem presidensial yang mana pengaturan semacam itu dapat menyebabkan sang presiden memilih lembaga yang paling menguntungkan proposalnya dalam kasus-perkasus.

Meski demikian, yang patut dipahami adalah meski parlemen terdiri dari dua majelis, tetapi kedua majelis bisa jadi tidak setara kekuasaannya. Menurut Andrew S. Ellis, bahwa sistem bikameral dapat digolongkan sebagai 'kuat' dan 'lemah' yaitu: pertama, dalam sistem yang 'kuat,' pembuatan undang-undang biasanya dimulai dari majelis manapun, dan harus dipertimbangkan oleh kedua majelis dalam forum yang sama sebelum bisa disahkan. Kedua, dalam sistem 'lunak,' majelis yang satu memiliki status yang lebih tinggi dari yang lain. Misalnya, majelis pertama mungkin dapat mengesampingkan penolakan atau amandemen RUU yang diajukan oleh majelis kedua, (Reni Dwi Purnomowati, 2005: 23).

\section{HASIL DAN PEMBAHASAN}

\section{Sejarah Kebutuhan Parlemen Dua Kamar di Indonesia}

Gagasan pembentukan DPD sebagai lembaga perwakilan daerah tidak terlepas dari bergulirnya semangat Reformasi akibat adanya krisis sosial, ekonomi, dan politik yang terjadi sejak 1997. Memasuki tahun 1999 terjadi perubahan penting dalam hal struktur kelembagaan 
pada sistem politik Indonesia. Melalui empat kali amandemen UndangUndang Dasar 1945 (UUD 1945) pada tahun 1999-2002, sistem politik Indonesia mengalami perubahan secara fundamental dari sistem otoritarian menjadi sistem politik yang demokratis selain itu dari sebuah sistem yang sentralistik menjadi desentralistik, (Frank Feulner, 2005: 140).

Salah satu perubahan yang penting dilakukan pada tahun 2001 adalah ketika Panitia Ad Hoc (PAH) I MPR dengan dibantu oleh Tim Ahli ditugaskan untuk membuat rancangan amandemen ketiga UUD 1945. Rancangan Amandemen UUD 1945 dari PAH I tersebut mengusulkan sistem bikameral - atau sistem dua dewan - di badan legislatif, hingga pada akhirnya terbentuklah sistem bikameral di Indonesia dengan adanya dua lembaga parlemen, yaitu lembaga DPR dan DPD selain berbagai perubahan lainnya.

Selanjutnya, dalam Perubahan Keempat tahun 2002, telah menetapkan komposisi Majelis Permusyawaratan Rakyat (MPR) baru yang terdiri dari anggota DPR ditambah anggota DPD. Keberadaan DPD ini dalam Undang-Undang Dasar Negara Republik Indonesia Tahun 1945 (UUD NRI Tahun 1945) adalah menggantikan Utusan Daerah sebagai lembaga negara baru yang diatur dalam konstitusi yang diisi oleh wakil daerah melalui Pemilu merupakan peningkatan dari pelaksanaan kedaulatan rakyat, (Amidhan, 2017: 115-116).

Merujuk hasil Amandemen Ketiga UUD 1945 pada tahun 2001 itu, disepakatinya pembentukan DPD. Lembaga legislatif baru ini dimaksudkan agar masalah-masalah yang dihadapi daerah menjadi perhatian besar oleh pemerintah pusat daripada masa lalu. Kehadiran DPD sebagai hasil dari gerakan reformasi yang mengakhiri kekuasaan Orde Baru pada 1998. Selama hampir 50 tahun, sebelum reformasi bergulir, dominasi pemerintah pusat atas daerah cukup kuat. Terutama di bidang politik dan ekonomi. Hal ini mengakibatkan 
keterbatasan partisipasi politik oleh masyarakat kecil, dan kebijakan ekonomi yang kurang memihak kepada kepentingan masyarakat di daerah.

Kehadiran DPD telah membangkitkan harapan masyarakat di daerah bahwa kepentingan dan aspirasi daerah dapat diangkat dan diperjuangkan di tingkat nasional. Keberadaan DPD diharapkan dapat menjamin kepentingan daerah sebagai bagian dari kepentingan nasional. Secara umum latar belakang dibentuknya DPD adalah sebagai berikut: pertama, memperkuat ikatan daerah-daerah dalam wadah Negara Kesatuan Republik Indonesia (NKRI) dan memperteguh persatuan kebangsaan seluruh daerah; kedua, meningkatkan agregasi dan akomodasi aspirasi kepentingan daerah-daerah dalam perumusan kebijakan nasional berkaitan dengan negara dan daerah-daerah; ketiga, meningkatkan percepatan demokrasi, pembangunan dan kemajuan daerah-daerah secara serasi dan seimbang; keempat, membangun mekanisme kontrol dan keseimbangan antar cabang kekuasaan negara dalam lembaga legislatif itu sendiri; dan kelima, menjamin dan menampung perwakilan daerah-daerah yang memadai untuk memperjuangkan aspirasi dan kepentingan daerah dalam lembaga legislatif, (dokumen: Sekilas Dewan Perwakilan Daerah Republik Indonesia, Dewan Perwakilan Daerah Republik Indonesia, tanpa nomor halaman).

Lembaga legislatif, yaitu DPD yang baru belakangan muncul ini merupakan amanat dari perubahan ketiga UUD 1945, yaitu dalam Pasal 22C, Pasal 22D, dan Pasal 22E. Selanjutnya dalam Perubahan Keempat UUD 1945, posisi DPD ini diatur lebih lanjut dalam konteks sebagai bagian dari MPR. Dalam Pasal 2 ayat (1) dikatakan bahwa "MPR terdiri atas anggota DPR dan anggota DPD yang dipilih melalui pemilihan umum dan diatur lebih lanjut dengan undang-undang." 
Konsep lembaga perwakilan rakyat di Indonesia semula bersifat unik karena adanya MPR yang punya fungsi "super" namun tidak bekerja sehari-hari dan ada pula DPR yang memegang legislatif rutin. Sejak perubahan keempat UUD 1945 tersebut, konsep lembaga perwakilan rakyat Indonesia berubah menjadi serupa dengan parlemen bikameral (dua kamar), hal mana selain DPR dikenal pula DPD sebagai lembaga legislatif. Namun masih saja ada keunikan, yaitu dengan tetap diakuinya MPR sebagai lembaga tersendiri, sehingga seakan-akan ada tiga lembaga perwakilan di Indonesia.

\section{Reformasi Menghadirkan Soft Bicameral}

Salah satu perubahan yang dilakukan terhadap UUD 1945 ialah dibentuknya lembaga baru yang bernama DPD. Raison d'etre dari keberadaan DPD, untuk mengakomodasikan semangat checks and balances tidak hanya antara pusat dan daerah, tetapi juga di dalam parlemen itu sendiri. Namun, tidak adanya posisi equal melainkan inequality (ketidaksetaraan) antara hubungan kerjasamanya dengan DPR.

Pada Perubahan Ketiga UUD 1945 hasil Sidang Tahunan MPR tahun 2001 mengadopsikan gagasan parlemen 'bikameral' yang bersifat 'soft.' Kedua kamar dewan perwakilan tersebut tidak dilengkapi dengan kewenangan yang sama kuat, yang lebih kuat tetap DPR, sedangkan kewenangan DPD hanya bersifat terbatas. Hal itu terjadi karena proyek amandemen ini ditangani kalangan MPR, dan karena semua anggota DPR yang juga sekaligus sebagai anggota MPR yang ikut merumuskan UUD 1945 mengenai fungsi dan kewenangan DPD, maka DPR dengan kewenangan yang ada lebih cenderung merumuskan lebih besar kewenangannya, melebihi kewenangan yang dimiliki DPD.

Idealnya, seperti dijelaskan di awal, bahwa posisi anggota DPD adalah para Duta Nusantara yang dipilih langsung oleh pemilih, sama 
halnya anggota DPR. Namun banyak pihak yang bertanya mengapa fungsinya sebagai lembaga perwakilan daerah dibuat menjadi sangat terbatas. Keberadaaannya seperti kerakap tumbuh di batu. Dilahirkan tetapi seolah tidak dikehendaki. Kehadirannya seolah diterima setengah hati. Hal itu benar-benar menjadi tanya dan meyedihkan berbagai kalangan. Biaya memilih dan dipilih anggota DPD sangat besar, namun fungsinya baru menjadi "pelengkap penyerta" di lembaga legislatif kita.

Setelah satu dekade lebih keberadaan DPD pasca reformasi yakni pada 1 Oktober 2004. DPD masih mengemban dua fungsi utama. Pertama, mengajukan usul ikut membahas dan memberikan pertimbangan terkait dengan bidang legislasi tertentu. Kedua, mengawasi pelaksanaan undang-undang berkaitan dengan masalahmasalah daerah.

Wewenang DPD memang masih jauh dari memadai untuk menjadi kamar kedua yang efektif dan setara dalam sebuah parlemen bikameral. Permasalahan antara DPR dengan DPD adalah kerdilnya fungsi DPD dalam konstitusi dan dari berbagai undang-undang turunannya. Kehadiran DPD sebagai lembaga perwakilan belum mengarah kepada adanya tugas, fungsi, dan wewenang yang sama dengan DPR. UUD 1945 yang mengatur DPD, dan undang-undang turunannya seperti undang-undang MPR, DPR, DPD, dan DPRD (disebut UU MD3), dalam hubungan DPR dan DPD, kedudukan DPD masih sangat lemah karena fungsinya hanya memberi pertimbangan kepada DPR.

Dari sisi konstitusi, proses amandemen UUD 1945 yang semula diharapkan akan mampu menjawab berbagai persoalan bangsa, ternyata tidak dilakukan secara tuntas, dan terkesan setengah hati. Bahkan proses pembentukan sebuah sistem yang kita kenal sebagai 
soft bicameral ini, diputuskan melalui kompromi bukan dengan mekanisme voting.

Dalam proses Amandemen untuk mencapai musyawarah mufakat terjadi "bargaining politics," ide mengenai DPD dipertukarkan dengan gagasan pemilihan presiden secara langsung antara dua fraksi terbesar di MPR, Fraksi Partai Golkar (F-PG) dan Fraksi Partai Demokrasi Indonesia Perjuangan (F-PDI-P). Demi diterima ide pemilihan presiden secara langsung, F-PG bersedia menerima weak bicameralism karena F-PDIP menolak strong bicameralism dengan alasan akan membawa Indonesia ke arah federalisme, akhirnya, wewenang DPD memang masih jauh dari memadai untuk menjadi kamar kedua yang efektif dan setara dalam sebuah parlemen bikameral. Kehadirannya seolah diterima setengah hati, (Yoyoh Rohaniah dan Efriza, 2016: 398).

Jika dipelajari lebih mendalam bahwa, dalam sistem dua kamar murni (strong bicameralism) kedua kamar tersebut diberi tugas dan wewenang menetapkan undang-undang. Artinya, setiap rancangan undang-undang yang telah disetujui DPR (sebagai Majelis Rendah) harus dibahas lebih lanjut dalam kamar kedua (sebagai Majelis Tinggi). Majelis Tinggi ini kemudian memutuskan, menerima seluruhnya atau menolak seluruhnya rancangan undang-undang yang telah disetujui DPR.

Dengan demikian, kalau Majelis Rendah memunyai hak amandemen, Majelis Tinggi tidak memunyai hak amandemen. Melihat pasal-pasal dalam UUD 1945 yang mengatur DPD, lembaga-lembaga ini tidak memunyai tugas dan wewenang seperti itu. Bahkan dalam UUD 1945 ditentukan, jumlah seluruh anggota DPD tidak lebih dari 1/3 jumlah anggota DPR. Itulah sebabnya, perubahan UUD 1945 tidak menganut sistem dua kamar murni (strong bicameralism), sehingga di lingkungan PAH I BP MPR muncul istilah soft bicameralism untuk 
menyebut bentuk sistem ini. Walaupun demikian DPD memunyai fungsi-fungsi, yaitu: fungsi legislasi (terbatas), fungsi pertimbangan (terbatas), dan fungsi pengawasan (terbatas).

Bagi DPD, kendati merupakan hasil politik reformasi, keberadaannya sudah menunjukan kiprah sebagai lembaga politik atau parlemen yang memerankan kamar kedua secara lunak (soft second chamber). Dengan demikian, sistem perwakilan kita, lebih tepat dikatakan menerapkan sistem "soft bicameralis" bukan sistem trikameral. Konsep trikameral yang secara konstitusional ada, kenyataannya secara politik hanya dipenuhi satu kamar, yakni DPR; dan juga tidak dapat dikatakan kita menganut trikameral sebab tugas MPR tidak ada kaitannya dengan fungsi lembaga legislatif (seperti pembuatan undang-undang atau legislasi), yakni: melainkan hanya menetapkan dan mengubah UUD, impeachment, dan melantik presiden dan wakil presiden.

Jadi, prinsip bikameral telah dipilih dan dijalankan, seperti: adanya lembaga DPD di samping lembaga DPR, mereka memainkan prinsip perwakilan yang berbeda, mereka menjalankan sidang-sidang terpisah, dan mereka punya sekretariat sendiri-sendiri. Walaupun DPD tidak memainkan peran sebagai lembaga legislatif (legislasi penuh), tetapi DPD memiliki fungsi-fungsi legislatif, pertimbangan, dan pengawasan (seluruhnya terbatas).

Dalam pada itu, meskipun kelembagaan DPD telah terbentuk, namun pelembagaan perwakilan wilayah (spartial representation), pada tingkat konstitusi maupun legislasi, tidak dengan sendirinya meningkatkan watak keterwakilan daerah, karena kekuasaan legislatif di tangan DPR sebagai wakil rakyat kini menjadi keniscayaan.

Sementara itu, DPD yang semestinya merupakan salah satu kamar dalam sistem perwakilan bikameral, yang memainkan fungsi sebagai penyalur aspirasi masyarakat daerah dalam pembuatan 
kebijakan di tingkat pusat, dan diharapkan dapat mencegah disahkannya perundang-undangan yang cacat dan ceroboh, serta melakukan pengawasan yang selama ini sejak Indonesia merdeka hingga penghujung 2020 ini, realitasnya, sistem kontrol hanya dilakukan satu kamar (only one eye), yakni DPR yang terdiri atas politikus dengan beragam kepentingan, sehingga DPD kini berfungsi sebagai kosmetik belaka dalam sistem checks and balances, akibat dipilihnya sistem soft bicameral tersebut (silahkan baca: Syafuan Rozi dan Efriza, 2010).

\section{Peran Menguat Tetapi Eksistensi Merosot}

Sepanjang menyangkut DPD, Mahfud MD berpendapat, bahwa saat terjadi tuntutan untuk menciptakan sistem yang menjamin checks and balances, dirancang sistem parlemen bikameral. DPD diposisikan seperti lembaga Senat seperti di Amerika Serikat yang akan berpasangan dengan DPR untuk memerankan lembaga parlemen. Namun perjalanan pembahasan ternyata yang disepakati MPR pada waktu itu sekadar DPD yang hadir secara konstitusional, namun peran dan fungsinya sangat sumir, dan tidak memunyai kewenangan memadai sebagai layaknya lembaga legislatif.

Walaupun kewenangannya masih sangat terbatas, namun keinginan untuk membangun sistem bikameral, menurut Denny Indrayana, bukannya tidak memunyai alasan yang kuat. Berdasarkan berbagai penelitian sebelumnya, ditemukan data bahwa sampai tahun 1990-an, memang dari 4 parlemen yang ada di dunia, 3 merupakan parlemen unikameral. Kecenderungan ini berubah, pada tahun 1996 dari 36 negara yang diteliti, 23 ternyata menganut sistem bikameral. Walaupun negara-negara yang menganut sistem bikameral itu bisa dibedakan menjadi yang weak bicameralism (bikameral yang lemah), 
atau strong bicameralism (bikameral yang kuat dan seimbang), (Bambang Sadono, 2017: 5).

Penataan kedudukan, fungsi, dan peran DPD sebagaimana ditegaskan dalam UUD 1945 pada dasarnya dimaksudkan untuk memperkuat ikatan daerah-daerah dalam wadah NKRI dan memperteguh persatuan kebangsaan seluruh daerah. Meski begitu, melihat realitasnya, diperlukan kembali penataan sistem ketatanegaraan melalui penyempurnaan konstitusi, inilah yang diperjuangkan oleh DPD dan berbagai kalangan yang mendukung terhadap penguatan kewenangan DPD, hal ini diharapkan harus bisa memenuhi kebutuhan ketatanegaraan dalam konteks kekinian, dan ke depan harus bisa menjawab tantangan yang akan terjadi. Sehingga amandemen tersebut tidak merupakan kesepakatan politik yang hampa yang hanya memenuhi tuntutan politik yang emosional dan parsial belaka. Usulan amandemen yang didorong oleh DPD bukan sebagai langkah politik yang pragmatis dan bersifat jangka pendek. Bahkan argumentasi mendasarnya adalah untuk membangun sistem dan manajemen lembaga dalam sistem ketatanegaraan yang menjamin akuntabilitas dan mempertegas sistem checks and balances.

Bahkan secara politik hukum, eksistensi DPD telah diperkuat oleh Mahkamah Konstitusi dengan Putusan Nomor 92/PUU-X/2012, dengan membangun purifikasi sistem bikameral yang kuat pasca amandemen UUD 1945. Penguatan itu merupakan penegasan fungsi legislasi DPD dalam ikut mengusulkan Rancangan Undang-Undang, dan ikut dalam pembahasan Tingkat I maupun II, pada materi legislasi yang terkait dengan Pasal 22D UUD 1945.

Pasca putusan 92/PUU-X/2012 telah muncul Undang-Undang baru tentang MPR, DPR, DPD, dan DPRD (UU MD3) yakni, UU Nomor 17 Tahun 2014. Namun, undang-undang ini tidak mengindahkan beberapa hasil dari putusan Mahkamah Konstitusi 92/PUU-X/2012. 
Hal ini memicu DPD mengajukan kembali judicial review, yang telah diputus oleh Mahkamah Konstitusi melalui Putusan Nomor 79/PUUXII/2014, hal mana putusan ini memperkuat putusan 92/PUUX/2012, (Bambang Sadono, 2017: 4).

Tafsir konstitusional Mahkamah Konstitusi dalam putusan Nomor 79/PUU-XII/2014, tanggal 22 September 2015 telah menegaskan kembali wewenang DPD terkait dengan pembahasan RUU dalam UU MD3 Tahun 2014, sebagai berikut:

1. Pasal 71 huruf c UU MD3 Tahun 2017, dinyatakan bertentangan dengan UUD 1945 dan tidak memunyai kekuatan hukum mengikat, sepanjang tidak dimaknai, "membahas rancangan undang-undang yang diajukan oleh Presiden, DPR, atau DPD yang berkaitan dengan otonomi daerah, hubungan pusat dan daerah, pembentukan dan pemekaran serta penggabungan daerah, pengelolaan sumber daya alam dan sumber daya ekonomi lainnya, serta perimbangan keuangan pusat dan daerah, dengan mengikutsertakan DPD sebelum diambil persetujuan bersama antara DPR dan Presiden."

2. Pasal 166 ayat (2) UU MD3 Tahun 2017, dinyatakan bertentangan dengan UUD 1945 dan tidak memunyai kekuatan hukum mengikat, sepanjang tidak dimaknai, "Rancangan undang-undang sebagai dimaksud pada ayat (1) beserta naskah akademik disampaikan secara tertulis oleh pimpinan DPD kepada pimpinan DPR dan Presiden."

3. Pasal 250 ayat (1) UU MD3 Tahun 2017, dinyatakan bertentangan dengan UUD 1945 dan tidak memunyai kekuatan hukum mengikat, sepanjang tidak dimaknai, "Dalam melaksanakan wewenang dan tugas sebagaimana dimaksud dalam Pasal 249, DPD memiliki kemandirian dalam menyusun anggaran yang dituangkan ke dalam program dan kegiatan disampaikan kepada Presiden untuk 
dibahas bersama DPR sesuai dengan ketentuan peraturan perundang-undangan."

4. Pasal 277 ayat (1) UU MD3/2017, dinyatakan bertentangan dengan UUD 1945 dan tidak memunyai kekuatan hukum mengikat, sepanjang tidak dimaknai, "Rancangan undang-undang sebagaimana dimaksud dalam Pasal 276 ayat (3) beserta naskah akademik disampaikan dengan surat pengantar pimpinan DPD kepada pimpinan DPR dan Presiden."

Selanjutnya, dapat dilihat dalam berikut ini:

Tabel 1.1

Hasil Putusan Mahkamah Konstitusi

\begin{tabular}{|c|c|c|}
\hline $\begin{array}{l}\text { Pasal dalam UU } \\
\text { MD3/2014 }\end{array}$ & $\begin{array}{c}\text { Substansi Pasca } \\
\text { Putusan Mahkamah } \\
\text { Konstitusi }\end{array}$ & Keterangan \\
\hline $\begin{array}{l}\text { Pasal } 71 \text { huruf c } \\
\text { c. membahas } \\
\text { rancangan } \\
\text { undang-undang } \\
\text { yang diajukan } \\
\text { oleh Presiden } \\
\text { atau DPR yang } \\
\text { berkaitan } \\
\text { dengan otonomi } \\
\text { daerah, } \\
\text { hubungan pusat } \\
\text { dan daerah, } \\
\text { pembentukan } \\
\text { dan pemekaran } \\
\text { serta } \\
\text { penggabungan } \\
\text { daerah, } \\
\text { pengelolaan } \\
\text { sumber daya } \\
\text { alam dan } \\
\text { sumber daya } \\
\text { ekonomi lainnya, } \\
\text { serta perimbangan } \\
\text { keuangan pusat }\end{array}$ & $\begin{array}{l}\text { "membahas } \\
\text { rancangan undang- } \\
\text { undang yang } \\
\text { diajukan oleh } \\
\text { Presiden, DPR, atau } \\
\text { DPD yang berkaitan } \\
\text { dengan otonomi } \\
\text { daerah, hubungan } \\
\text { pusat dan daerah, } \\
\text { pembentukan dan } \\
\text { pemekaran serta } \\
\text { penggabungan } \\
\text { daerah, pengelolaan } \\
\text { sumber daya alam } \\
\text { dan sumber daya } \\
\text { ekonomi lainnya, } \\
\text { serta perimbangan } \\
\text { keuangan pusat dan } \\
\text { daerah, dengan } \\
\text { mengikutsertakan } \\
\text { DPD sebelum diambil } \\
\text { persetujuan bersama } \\
\text { antara DPR dan } \\
\text { Presiden." }\end{array}$ & $\begin{array}{l}\text { DPD dilibatkan } \\
\text { dalam pembahasan } \\
\text { rancangan undang- } \\
\text { undang yang terkait } \\
\text { lingkung } \\
\text { kewenangan sampai } \\
\text { sebelum diambil } \\
\text { persetujuan } \\
\text { bersama antara } \\
\text { DPR dan Presiden. }\end{array}$ \\
\hline
\end{tabular}




\begin{tabular}{|c|c|c|}
\hline $\begin{array}{l}\text { Pasal dalam UU } \\
\text { MD3/2014 }\end{array}$ & $\begin{array}{c}\text { Substansi Pasca } \\
\text { Putusan Mahkamah } \\
\text { Konstitusi }\end{array}$ & Keterangan \\
\hline $\begin{array}{l}\text { dan daerah, } \\
\text { dengan } \\
\text { mengikutsertaka } \\
\text { n DPD sebelum } \\
\text { diambil } \\
\text { persetujuan } \\
\text { bersama antara } \\
\text { DPR dan } \\
\text { Presiden. }\end{array}$ & & \\
\hline $\begin{array}{l}\text { Pasal } 166 \text { ayat (2): } \\
\text { (2). Rancangan } \\
\text { undang-undang } \\
\text { sebagaimana } \\
\text { dimaksud pada } \\
\text { ayat (1) beserta } \\
\text { naskah } \\
\text { akademik } \\
\text { disampaikan } \\
\text { secara tertulis } \\
\text { oleh pimpinan } \\
\text { DPD kepada } \\
\text { pimpinan DPR. }\end{array}$ & $\begin{array}{l}\text { "Rancangan undang- } \\
\text { undang } \\
\text { sebagaimana pada } \\
\text { ayat (1) beserta } \\
\text { naskah akademik } \\
\text { disampaikan secara } \\
\text { tertulis oleh pimpinan } \\
\text { DPD kepada } \\
\text { pimpinan DPR dan } \\
\text { Presiden." }\end{array}$ & $\begin{array}{l}\text { Selain kepada DPR, } \\
\text { DPD juga } \\
\text { menyampaikan } \\
\text { Rancangan } \\
\text { Undang-Undang } \\
\text { beserta Naskah } \\
\text { Akademik } \\
\text { Rancangan } \\
\text { Undang-Undang } \\
\text { tersebut kepada } \\
\text { Presiden. }\end{array}$ \\
\hline $\begin{array}{l}\text { Pasal } 250 \text { ayat (1) } \\
\text { (1). Dalam } \\
\text { melaksanakan } \\
\text { wewenang dan } \\
\text { tugas } \\
\text { sebagaimana } \\
\text { dimaksud Pasal } \\
249 \text {, DPD } \\
\text { menyusun } \\
\text { anggaran yang } \\
\text { dituangkan } \\
\text { dalam program } \\
\text { dan kegiatan } \\
\text { sesuai dengan } \\
\text { ketentuan } \\
\text { peraturan } \\
\text { perundang- } \\
\text { undangan. }\end{array}$ & $\begin{array}{l}\text { "Dalam } \\
\text { melaksanakan } \\
\text { wewenang dan tugas } \\
\text { sebagaimana } \\
\text { dimaksud dalam } \\
\text { Pasal 249, DPD } \\
\text { memiliki } \\
\text { kemandirian dalam } \\
\text { menyusun anggaran } \\
\text { yang dituangkan ke } \\
\text { dalam program dan } \\
\text { kegiatan } \\
\text { disampaikan } \\
\text { kepada Presiden } \\
\text { untuk dibahas } \\
\text { bersama DPR } \\
\text { sesuai dengan } \\
\text { ketentuan peraturan } \\
\text { perundang- } \\
\text { undangan." }\end{array}$ & $\begin{array}{l}\text { DPD memiliki } \\
\text { kemandirian dalam } \\
\text { menyusun } \\
\text { anggaran yang } \\
\text { disampaikan } \\
\text { kepada Presiden } \\
\text { untuk dibahas } \\
\text { bersama DPR. }\end{array}$ \\
\hline
\end{tabular}




\begin{tabular}{|c|c|c|}
\hline $\begin{array}{l}\text { Pasal dalam UU } \\
\text { MD3/2014 }\end{array}$ & $\begin{array}{c}\text { Substansi Pasca } \\
\text { Putusan Mahkamah } \\
\text { Konstitusi }\end{array}$ & Keterangan \\
\hline $\begin{array}{l}\text { Pasal } 277 \text { ayat (1): } \\
\text { (1). Rancangan } \\
\text { undang-undang } \\
\text { sebagaimana } \\
\text { dimaksud dalam } \\
\text { Pasal } 276 \text { ayat } \\
\text { (3) beserta } \\
\text { naskah } \\
\text { akademik } \\
\text { disampaikan } \\
\text { dengan surat } \\
\text { pengantar } \\
\text { pimpinan DPD } \\
\text { kepada } \\
\text { pimpinan DPR } \\
\text { dengan } \\
\text { tembusan } \\
\text { kepada Presiden }\end{array}$ & $\begin{array}{l}\text { "Rancangan undang- } \\
\text { undang } \\
\text { sebagaimana } \\
\text { dimaksud Pasal } 276 \\
\text { ayat (3) beserta } \\
\text { naskah akademik } \\
\text { disampaikan dengan } \\
\text { surat pengantar } \\
\text { pimpinan DPD } \\
\text { kepadar pimpinan } \\
\text { DPR dan Presiden." }\end{array}$ & $\begin{array}{l}\text { Selain kepada DPR, } \\
\text { DPD juga } \\
\text { menyampaikan } \\
\text { Rancangan } \\
\text { Undang-Undang } \\
\text { beserta Naskah } \\
\text { Akademik } \\
\text { Rancangan } \\
\text { Undang-Undang } \\
\text { tersebut kepada } \\
\text { Presiden. }\end{array}$ \\
\hline
\end{tabular}

(Sumber: Panitia Perancang Undang-Undang - Law Center, 2017: 40-41)

Melalui Putusan Mahkamah Konstitusi Nomor 92/PUU-X/2012 atau Nomor 79/PUU-XII/2014, hal mana kewenangan legislasi DPD kembali dipulihkan sesuai dengan mandat UUD 1945. Dalam proses legislasi DPD berwenang menyusun Program Legislasi Nasional (Prolegnas), mengajukan rancangan undang-undang dan ikut serta dalam proses pembahasan rancangan undang-undang secara tripartit bersama DPD dan pemerintah.

Meski demikian, tetap saja dalam prakteknya, sebenarnya kedudukan DPD masih lemah dibandingkan DPR dalam menjalankan fungsi legislasi karena memang secara konstitusional Pasal 20 UUD 1945 telah membatasi kewenangan DPD. Melihat lemahnya kedudukan DPD dalam fungsi legislasi tersebut, maka dapat dikatakan bahwa peran DPD hanya bersifat penunjang atau auxiliary terhadap fungsi DPD di bidang legislasi karena perannya lebih kurang hanya sebagai 
co-legislator, bahkan I Wayan Sudirta mengatakan bahwa berdasarkan kewenangannya tersebut DPD tidak dapat disebut sebagai majelis tinggi melainkan hanya suatu "badan pertimbangan" (advisory body) karena bahkan dalam area hal mana DPD dapat memberikan pertimbangan (advice) pun juga dibatasi, (I Wayan Sudirta, 2017: 70$71)$.

Tentu saja hal ini tampak tidak sebanding dengan persyaratan untuk menjadi anggota yang lebih berat daripada persyaratan untuk menjadi anggota DPR, karena anggota DPD sebagaimana DPR samasama dipilih oleh rakyat, hal mana daerah pemilihan untuk menjadi anggota DPD adalah provinsi dengan kuota masing-masing empat orang untuk setiap provinsi. Sedangkan untuk anggota DPR daerah pemilihannya meliputi wilayah di bawah provinsi seperti kabupaten dan kota dengan jumlah kursi yang lebih banyak dibanding DPD. Tatkala kesadaran ini telah dirasakan sejak periode pertama tahun 2004, sehingga hingga kini muncul keinginan agar dilakukannya amandemen kelima terhadap UUD 1945, keinginan tersebut terus digulirkan oleh DPD.

Di saat dukungan terhadap DPD mulai menguat, ternyata eksistensi DPD hingga tahun keempatnya, memang tak bisa dimungkiri nyaris belum terdengar prestasi kinerja para anggotanya sebagai representasi daerah, mereka justru terlihat semakin merosot popularitasnya, di awali dari tertangkap tangan dalam perkara korupsi Ketua DPD Irman Gusman, lalu konflik perebutan kursi kepemimpinan sampai dengan pencalonan anggotanya dalam Pemilu Serentak 2019 mendatang yang menggerus eksistensi DPD, sebab selain Ketua DPD Oesman Sapta Odang menjadi Ketua Umum Partai Hanura juga beberapa anggota DPD bergabung dalam kepengurusan partai tersebut, dan terakhir terpilihnya sosok kontroversial La Nyalla menjadi Ketua DPD RI. 
Persoalan dari Kasus Oesman Sapta tentu saja bertentangan dengan tujuan dari keberadaan DPD, yang secara konsep ketatanegaraan merupakan suatu institusi yang merepresentasikan wilayah. Maka, ketika sejumlah anggota DPD justru menjadi pengurus partai politik, tentu terjadi disorientasi fungsi DPD, mereka tak lagi murni berlaku mewakili daerahnya. Padahal DPD sendiri saat ini, berdasarkan putusan Mahkamah Konstitusi Nomor 79/PUU-XII/2014, bahwa dalam proses legislasi DPD sudah mulai menguat, hal mana DPD berwenang menyusun Program Legislasi Nasional (Prolegnas), mengajukan rancangan undang-undang dan ikut serta dalam proses pembahasan rancangan undang-undang secara tripartit DPR bersama Pemerintah dan DPD, bahkan DPD sendiri saat ini telah memiliki wewenang baru, yakni pengawasan dan evaluasi terhadap peraturan daerah (Perda) seperti diatur dalam UU MD3 tahun 2018. Jadi dengan segala keluhan dan keterbatasan wewenang, semestinya anggota DPD tetap memaksimalkan wewenangnya dengan meningkatkan checks and balances sebagai kamar kedua di parlemen.

\section{KESIMPULAN}

Dalam 16 tahun usianya, memang terjadi evolusi fungsi legislasi DPD, juga dalam upaya agregasi dan artikulasi kepentingan. Namun, selama periode kesatu (2004-2009), kedua (2009-2014), ketiga (20142019), dan keempat (2019-2024) DPD, evolusi tersebut kurang optimal mengejawantahkan nilai-nilai demokrasi perwakilan. Pimpinan/anggota DPD tetap saja kesulitan untuk menyerap, menghimpun, menampung, dan menindaklanjuti aspirasi masyarakat dan daerah, seiring pemenuhan tuntutan berbangsa dan bernegara sekaligus peningkatan peran dan tanggung jawab lembaga perwakilan ini. 
'Kerja politik' DPD yang usianya memasuki tahun keenambelas itu, persoalan antar kedua lembaga perwakilan masih terus bergulir. Problema paling mendasar ialah mewujudkan proses legislasi model tripatrit DPR-DPD bersama Presiden. Pasca putusan MK No. 92/PUUX/2012, atau Nomor 79/PUU-XII/2014, DPD yang notabene main state organ harus gencar mensosialisasikan konsekuensi atas keputusan Mahkamah Konstitusi itu, karena proses legislasi model tripatrit yang melibatkan tiga pihak, yakni DPR, DPD, dan Presiden, (Yoyoh Rohaniah dan Efriza, 2016). Peran DPD khususnya dalam hal legislasi sudah menguat, hanya persoalannya DPD dihadapkan pada resistensi DPR yang begitu tinggi, selain menguatnya konflik internal antar anggota yang memengaruhi kelembagaan, serta terjadinya kemerosotan nilai dalam memperjuangkan hasil kerja dan kinerjanya agar lebih baik.

Bahkan, DPR dapat saja disinyalir kembali mengabaikan putusan Mahkamah Konstitusi, seperti terjadi pada 2012 itu, UU No. 17 Tahun 2014 tentang MPR, DPR, DPD, dan DPRD (MD3) disusun dengan tidak mengindahkan putusan tersebut. Keadaan itu yang memantik langkah hukum DPD. Mahkamah Konstitusi untuk kali kedua (22 September 2015) kembali telah mengambil keputusan tepat dengan memenangkan sebagian tuntutan DPD - terutama yang berkaitan dengan ikhtiar menempatkan DPD sejalan dengan DPR dalam tugas dan fungsi sesuai dengan Pasal 22D UUD 1945. Keputusan itu telah mengembalikan sistem checks and balances di tubuh parlemen. DPD sebagai salah satu kamar di parlemen memiliki kembali wewenang mengimbangi kamar lain, yakni DPR.

Selama ini, fungsi dan relasi legislasi DPD dianggap seperti dibonsai oleh DPR saat sebuah rancangan undang-undang masuk proses pembahasan. Meski kenyataan itu tidak dapat dinafikan, tetapi DPD sesungguhnya masih bisa memaksimalkan peran dan fungsinya seandainya bisa menggerakkan partisipasi publik secara efektif pada 
tingkat nasional maupun daerah. DPD pun tak luput untuk kita tunjuk kesalahannya, karena DPD melupakan peran yang semestinya DPD harus kembali melibatkan publik, memperoleh simpatik publik, bukan terjerembab oleh konflik kepentingan anggotanya seperti perebutan kursi pimpinan DPD, inilah arah langkah DPD yang perlu dilakukan ke depan.

Para anggota DPD dipilih secara langsung oleh rakyat daerah, meski dalam perkembangannya calon anggota legislatif (Caleg) DPD tidak lagi 'perseorangan' murni. Legitimasi yang sangat kuat tersebut merupakan modal penting yang dimiliki anggota DPD untuk mengerakkan publik dan memperoleh dukungan dari mereka. Berbeda dengan anggota DPR, anggota DPD lebih otonom dan independen dalam memperjuangkan kemajuan pembangunan di daerah. Nyatanya, kesadaran ini sudah mulai terkikis, malah DPD diibaratkan seperti Dewan Perwakilan Daerah dari Partai Politik, bukan Dewan Perwakilan Daerah yang merupakan institusi parlemen sebagai kamar kedua.

Setelah satu dekade lebih berjalan, kritik terhadap otonomi daerah dalam kerangka hubungan pusat-daerah terus bermunculan. Hubungan pusat-daerah yang masih menyimpan banyak problem merupakan persoalan lain, isu penting yang masih dan akan terus relevan bagi penguatan peran DPD. Pembangunan belum merata ada ketimpangan antarwilayah, antarpulau, antardaerah, dan hal-hal spesifik yang terkait misalnya, persoalan kewilayahan, provinsi kelautan, dan daerah perbatasan. Masyarakat di daerah menunggu kiprah DPD untuk membuat Indonesia lebih adil, lebih merata, dan setara.

DPD dalam peran di perpolitikan nasional, meski fungsi dan kerjanya terbatas, DPD ibarat civil society tetapi berbentuk 'Raksasa' dan dibiayai negara. Tidak perlu lagi terus mempersoalkan lemahnya kedudukan DPD dalam sistem keparlemenan di Indonesia, dengan 
selalu menuntut Amandemen Kelima UUD 1945, sebab keinginan Amandemen tanpa dipertimbangkan secara keseluruhan pengaturannya dengan jelas akan menimbulkan permasalahan kelak antara lain, banyaknya penumpang gelap utamanya agenda terselubung partai-partai politik seperti setelah Pilpres 2014 dan 2019 lalu, bahwa beberapa partai yang kalah menggulirkan isu pengembalian pemilihan presiden melalui MPR tidak lagi secara langsung.

Oleh karena itu, DPD periode keempat ini, tidak perlu lagi selalu mempersoalkan eksistensinya dengan terus melakukan judicial review ke Mahkamah Konstitusi atau terus menggulirkan amandemen ke-5 UUD 1945. DPD hanya perlu meningkatkan kerja politiknya, dan kembali melibatkan publik. Inilah arah langkah DPD semestinya ke depan. Terlepas dari kuat atau lemahnya kedudukan DPD dalam sistem parlemen di Indonesia, keberadaan DPD telah terbukti mampu memberikan simulasi positif terhadap kemajuan demokrasi di Indonesia, sebagai bukti kiprahnya selama satu dekade ini kepada rakyat, bangsa, dan negara, DPD telah menghasilkan keputusan totalnya mencapai 494 keputusan, dan pasca putusan Mahkamah Konstitusi, DPD yang notabene main state organ harus gencar mensosialisasikan konsekuesinya proses legislasi model tripatrit di Indonesia dengan model tiga pihak, DPR, DPD, dan Presiden. Dan semestinya, optimisme kerja politik DPD periode 2019-2024 ini, harus tetap dipelihara, untuk lebih bergairah menggerakkan perubahan dan kembali melibatkan publik dalam dinamika hubungan pusat dan daerah. Jika DPD mau dan mampu! 


\section{DAFTAR PUSTAKA}

\section{A. Buku}

Al Atok, A. Rosyid, Konsep Pembentukan Peraturan Pembentukan Peraturan Perundang-Undangan: Teori, Sejarah dan Perbandingan dengan Beberapa Negara Bikameral, (Malang: Setara Press, 2015).

Asshiddiqie, Jimly, Pengantar Hukum Tata Negara Jilid II, (Jakarta: Sekretariat Jenderal dan Kepaniteraan Mahkamah Konstitusi, 2006).

-------, Pokok-pokok Hukum Tata Negara Pasca Reformasi, (Jakarta: Bhuana Ilmu Populer, 2007).

Nazir, M., Metode Penelitian, Jakarta: Ghalia Indonesia, 2003.

Panitia Perancang Undang-Undang - Law Center, Peta Jalan Legislasi DPD RI, Jakarta: DPD RI, 2017.

Purnomowati, Reni Dwi, Implementasi Sistem Bikameral dalam Parlemen Indonesia, (Jakarta: RajaGrafindo Persada, 2005).

Yoyoh Rohaniah dan Efriza, Handbook Sistem Politik Indonesia Menjelajahi Teori dan Praktik, Malang: Intrans Publishing, 2016.

Rozi, Syafuan dan Efriza, Parlemen Indonesia Geliat Volksraad Hingga DPD, Menembus Lorong Waktu Doeloe, Kini, dan Nanti, Bandung: Alfabeta, 2010.

\section{B. Lain-lain (Dokumen, Jurnal, dan Majalah)}

Dokumen, Sekilas Dewan Perwakilan Daerah Republik Indonesia, Dewan Perwakilan Daerah Republik Indonesia, tanpa nomor halaman.

Majalah Figur, Menyoal Kewenangan DPD (Dewan Perwakilan Daerah), Edisi XIII, 2007.

Ahmad Farhan Hamid, DPD RI dan Masa Depan Demokrasi Indonesia, dalam Jurnal Ketatanegaraan, Vol. 003/Juni 2017.

Amidhan, "DPD dan Harapan Kewenangan Legislasi," Jurnal Ketatanegaraan, Vol. 003, Juni 2017.

Bambang Sadono, Politik Hukum DPD RI Dalam Sistem UUD 1945 Pasca Amandemen, dalam Jurnal Majelis, Edisi 01/Tahun 2017.

Frank Feulner, Menguatkan Demokrasi Perwakilan di Indonesia: Tinjauan Kritis Terhadap Dewan Perwakilan Daerah, dalam Jentera, Negara dan Kekuasaan, Jakarta, edisi 8 tahun III, 2005.

I Wayan Sudirta, Pemikiran Penguatan DPD Melalui Amandemen UUD 1945, dalam Jurnal Ketatanegaraan, Volume 003/Juni 2017. 